\title{
HYDROLOGICAL INVESTIGATIONS AT BIAFO GLACIER, KARAKORAM RANGE, HIMALAYA; AN IMPORTANT SOURCE OF WATER FOR THE INDUS RIVER
}

\author{
by \\ K. Hewitt, C.P. Wake*, G.J. Young, and C. David ${ }^{\dagger}$ \\ (Snow and Ice Hydrology Project, Wilfrid Laurier University, Waterloo, Ontario N2L 3C5, Canada)
}

\section{ABSTRACT}

Over $80 \%$ of the flow of the Upper Indus River is derived from less than $20 \%$ of its area: essentially from zones of heavy snowfall and glacierized basins above $3500 \mathrm{~m}$ elevation. The trans-Himalayan contribution comes largely from an area of some $20000 \mathrm{~km}^{2}$ of glacierized basins, mostly along the axis of the Greater Karakoram range and especially from $20-30$ of the largest glacier basins. Very few glaciological investigations have so far been undertaken in this the major glacierized region of Central Asia. Biafo Glacier, one of the largest of the Karakoram glaciers, drains south-eastwards from the central Karakoram crest. Its basin covers a total area of $853 \mathrm{~km}^{2}, 628 \mathrm{~km}^{2}$ of which are permanent snow and ice, with $68 \%$ of the glacier area forming the accumulation zone. This paper describes investigations of snow accumulation, ablation, glacier movement, and glacier depth undertaken in the period 1985-87, set against a background of investigations carried out over the last 130 years. Biafo Glacier differs from most of the other Karakoram glaciers in being nourished mainly by direct snowfall rather than by avalanching; this has the advantage of allowing extensive investigation of accumulation over a broad range of altitude.

Snow-accumulation studies in the Biafo Glacier basin have indicated that annual accumulation varies from 0.9 to $1.9 \mathrm{~m}$ of water equivalent between 4650 and $5450 \mathrm{~m}$ a..s.1. This suggests an annual moisture input above the equilibrium line of approximately $0.6 \mathrm{~km}^{3}$. Monopulse radar measurements indicate the presence of ice thickness as great as $1400 \mathrm{~m}$ at the equilibrium line, although these results may not be completely reliable. Mean surface velocity during the summer of $0.8 \mathrm{~m} \mathrm{~d}^{-1}$ has been measured near to the equilibrium line. Calculations of annual ice flux through the vertical cross-profile at the equilibrium line indicate a throughput of $0.7 \mathrm{~km}^{3} \mathrm{a}^{-1}$. Estimates from stake ablation measurements also suggest that ice loss on Biafo Glacier is about $0.7 \mathrm{~km}^{3} \mathrm{a}^{-1}$. The close agreement between these three sets of measurements is reassuring, indicating that the ablation zone of Biafo Glacier, whose area covers $0.09 \%$ of the whole Upper Indus basin, produces approximately $0.9 \%$ of the total run-off. However, it should be mentioned that this estimate does not include water originating from seasonal snow melt, either above or below the equilibrium line, or from rainfall. Net annual ice losses due to wastage of the glacier since 1910 are probably of the order of $0.4-0.5 \mathrm{~m} \mathrm{a}^{-1}$; this would represent between 12 and $15 \%$ of annual water yield from melting ice.

* Present address: Glacier Research Group, Institute for the Study of Earth, Ocean and Space, University of New Hampshire, Durham, NH 03824, U.S.A.

+ Present address: Department of Geography, University of Ottawa, Ottawa, Ontario KIN 6N5, Canada.

\section{INTRODUCTION: KARAKORAM GLACIERS AND} WATER SUPPLY

Biafo Glacier drains south-eastwards from the main watershed divide of the central Karakoram Range in south Central Asia (Fig. 1). It is the second longest of the Karakoram glaciers at $68 \mathrm{~km}$, and its area of $628 \mathrm{~km}^{2}$ is the third largest. It is the fourth largest valley glacier in Asia, and lies in that continent's largest concentration of perennial snow and glaciers, if the Arctic island of Novaya Zemlya is excluded (Wissman, 1959). The glacierized area of the Karakoram Range itself covers about $15000 \mathrm{~km}^{2}$; the ten largest glaciers comprise over one-third of this area, Biafo Glacier alone accounting for about $4 \%$ of coverage.

Hydrographs of rivers draining the Karakoram, such as the Hunza, Braldu, and Shyok, indicate that their flow is dominated by melt water from glacier basins (Fig. 2). Some $80-90 \%$ of the discharge occurs after snow cover has disappeared from areas below about $4500 \mathrm{~m}$ a.s.1., and at a time when rapid melting takes place between 3000 and $4500 \mathrm{~m}$ on the middle and lower zones of the glaciers. It may be that considerable quantities of melt water from

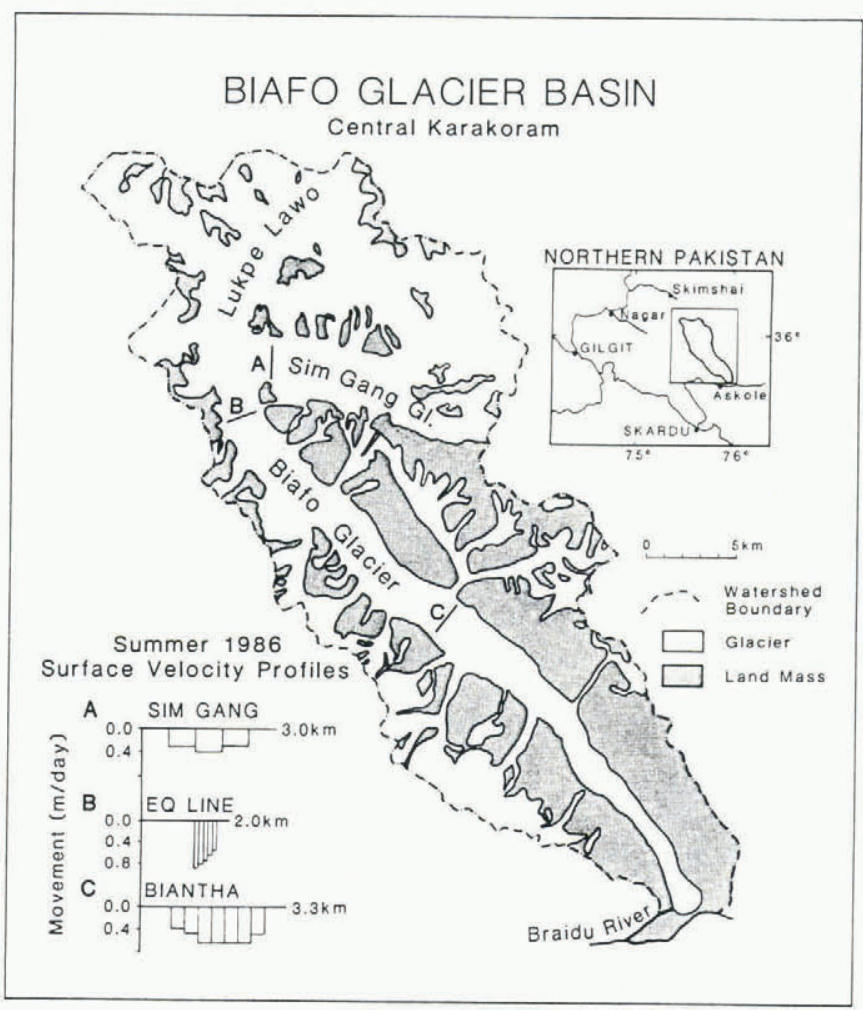

Fig. 1. Biafo Glacier basin, showing its location in northern Pakistan, and measurement locations. 


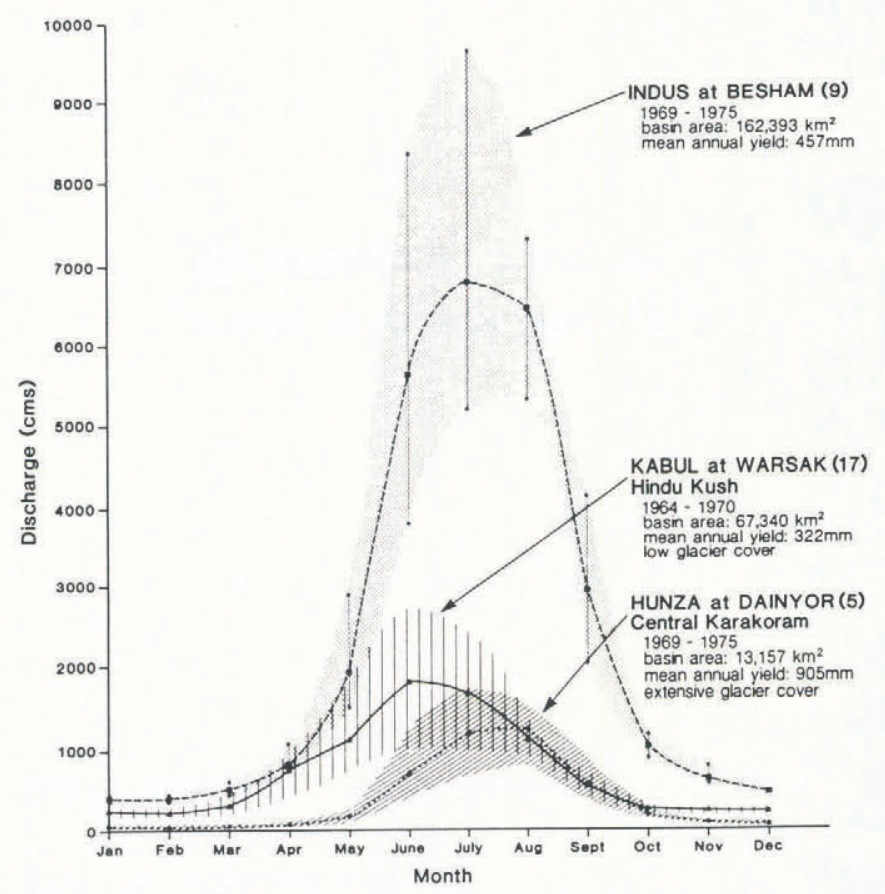

Fig. 2. Selected hydrographs within the Upper Indus basin.

snow on the glacier surfaces are stored englacially for periods of up to a few weeks before conduits within the ice begin to open up. Over a period of 6-8 weeks in summer, melt rates here are in the range $50-100 \mathrm{~mm} \mathrm{~d}^{-1}$ for relatively clean ice; this accounts for the major contribution to the flow from the glacier basins in the months of July and August. Although most of the region is snow-covered for some part of the winter, the water content of the snow-pack below about $3500 \mathrm{~m}$ is usually less than $150 \mathrm{~mm}$. Above this elevation, however, snowfall increases rapidly reaching values of about $1500 \mathrm{~mm}$ at $5000 \mathrm{~m}$ elevation. Run-off derived from seasonal snow may therefore make a significant contribution to stream flow. Below $4000 \mathrm{~m}$, there is in most years a prolonged and intense summer drought. Glacier termini generally lie in these semi-arid and arid elevational bands, and this is the case for the terminus of Biafo Glacier. Thus, the glaciers appear as the major water stores and water sources for the trans-Himalayan Indus and Yarkand Rivers. The paper reports on the work conducted in the years 1985-87 on Biafo Glacier and its surroundings in order to attempt to describe its hydrological behaviour and to estimate its contribution to the run-off from the Upper Indus basin. Additional information may be found in Hewitt (1985) and in Snow and Ice Hydrology Reports $(1986,1987)$.

\section{THE BIAFO GLACIER SYSTEM}

Perennial snow and ice covers about $60 \%$ of the Biafo Glacier basin area, and the accumulation zone comprises two-thirds of that $60 \%$ (Fig. 3). The pattern and maximum retreat of seasonal snow cover varies considerably from year to year, but it is estimated that for the last decade the equilibrium line has been at about $4650 \mathrm{~m}$. The upper glacier consists mainly of extensive open and gently sloping accumulation areas of the Sim Gang and Lukpe Lawo (Fig. 4); the latter is Sir Martin Conway's "Snow Lake". The main component of its surface area lies between 4500 and $5700 \mathrm{~m}$ a.s.l., where the glacier is largely nourished by snowfall. It is unusual among Karakoram glaciers, which are predominantly avalanche and ice-fall nourished, and of the incised reservoir (Firnkettle) or avalanche (Turkestan) glacio-morphological types. However, five of the ten largest glaciers in the Karakoram range including Biafo Glacier are of the firn-basin or "Alpine" types (Visser and Visser-Hooft, 1935-38; Wissman, 1959; Kick, 1964). The Biafo Glacier ablation zone consists mainly of a gently sloping ice stream, $2-3 \mathrm{~km}$ wide (Fig. 5). Down to about $3600 \mathrm{~m}$ a.s.l., a fine dusting of debris may be found over most of the ice. Below this altitude, thick medial and lateral morainic materials spread over the surface, which for the lower $8 \mathrm{~km}$ is almost completely masked by them. In all, about $25 \mathrm{~km}^{2}$ of the active glacier is blanketed with heavy moraine which leads to the much-reduced melting and controls the surface topography of the ice there. Most of the large Karakoram glaciers have even greater debris covers, probably reflecting higher amounts of avalanche nourishment and the entrainment of rock-wall debris that accompanies this process.

The debris-covered terminal lobe of Biafo Glacier spreads into the Braldu Valley at about $3100 \mathrm{~m}$ a.s.1. The complex suite of terminal moraines recording the advances and retreats of this century is unusual for Karakoram glaciers. Mega-ripples and other features of large-scale flooding across the pro-glacial plain indicate that Biafo Glacier has dammed the Braldu River in the past, resulting in major outburst floods (Hewitt, 1964, 1982). None of these seems to have occurred since the late eighteenth century, although the presence of ice across the river was reported on many occasions until about 1912. There are reports including many sketch maps, drawings, photographs, and some actual surveys of the terminus for the years since 1857 (Hewitt, 1968), and these provide one of the best records of the terminal behaviour of Karakoram glaciers. From 1910 to the $1970 \mathrm{~s}$, the glacier was involved in the pattern of retreat found throughout the Karakoram. Between 1975 and 1985 it had re-advanced by about $1 \mathrm{~km}$.

The ablation zone was explored by Godwin-Austen in 1861 , the upper basin by Conway in 1892 . The lower $35 \mathrm{~km}$ of ice are flanked by a prominent system of lateral morainic ridges and broad depositional terraces or troughs, known as "ablation valleys" (Visser and Visser-Hooft, 1935-38). Until the first decade of this century, visitors reported and photographed the ice standing higher than these features in many sections, shedding debris and melt water on to them. In recent decades the ice has thinned often by as much as tens of metres below them. On the basis of the trim-line height and thickness of terminal lobe in 1910, the glacier is calculated to have lost at least $2 \mathrm{~km}^{3}$ of its ice mass between 1910 and 1960. The long-term discharge records for the Upper Indus indicate that run-off for the period 1910-65 was higher, on the average, than that for 1869-1910. Climatic evidence suggests that this was mainly accounted for by glacier wastage rather than by increased snowfall (Hewitt, 1968) (see Fig. 6).

\section{Biafo Glacier Basin}

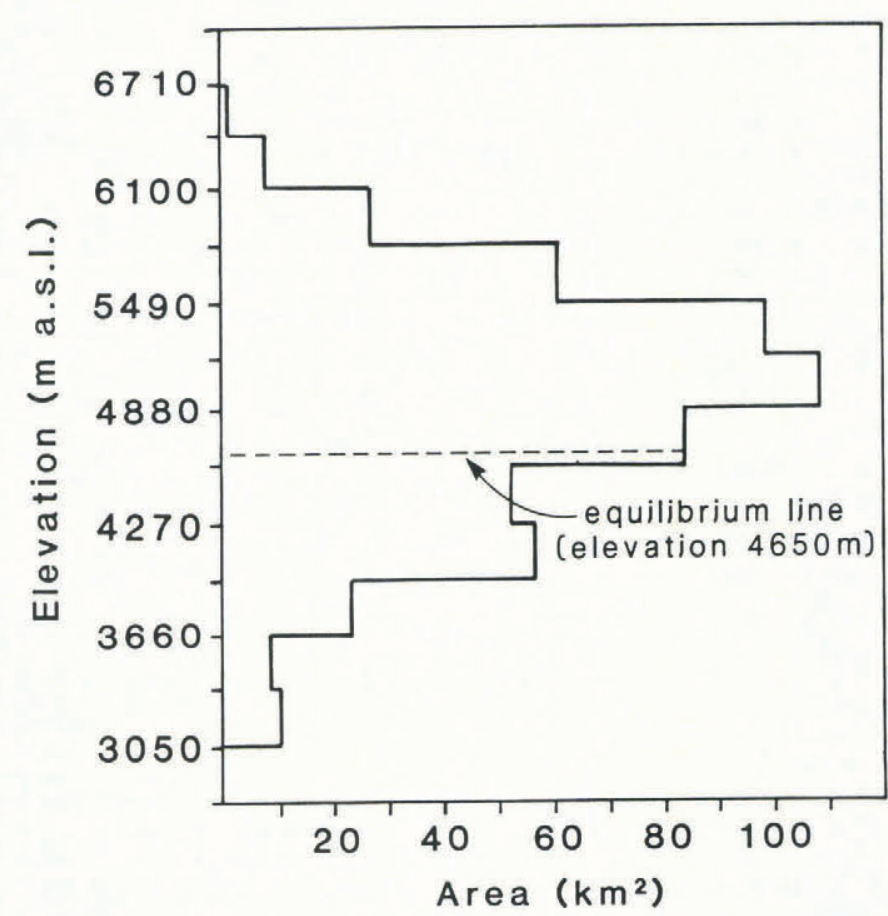

Fig. 3. Hypsometric curve for the Biafo Glacier basin. 


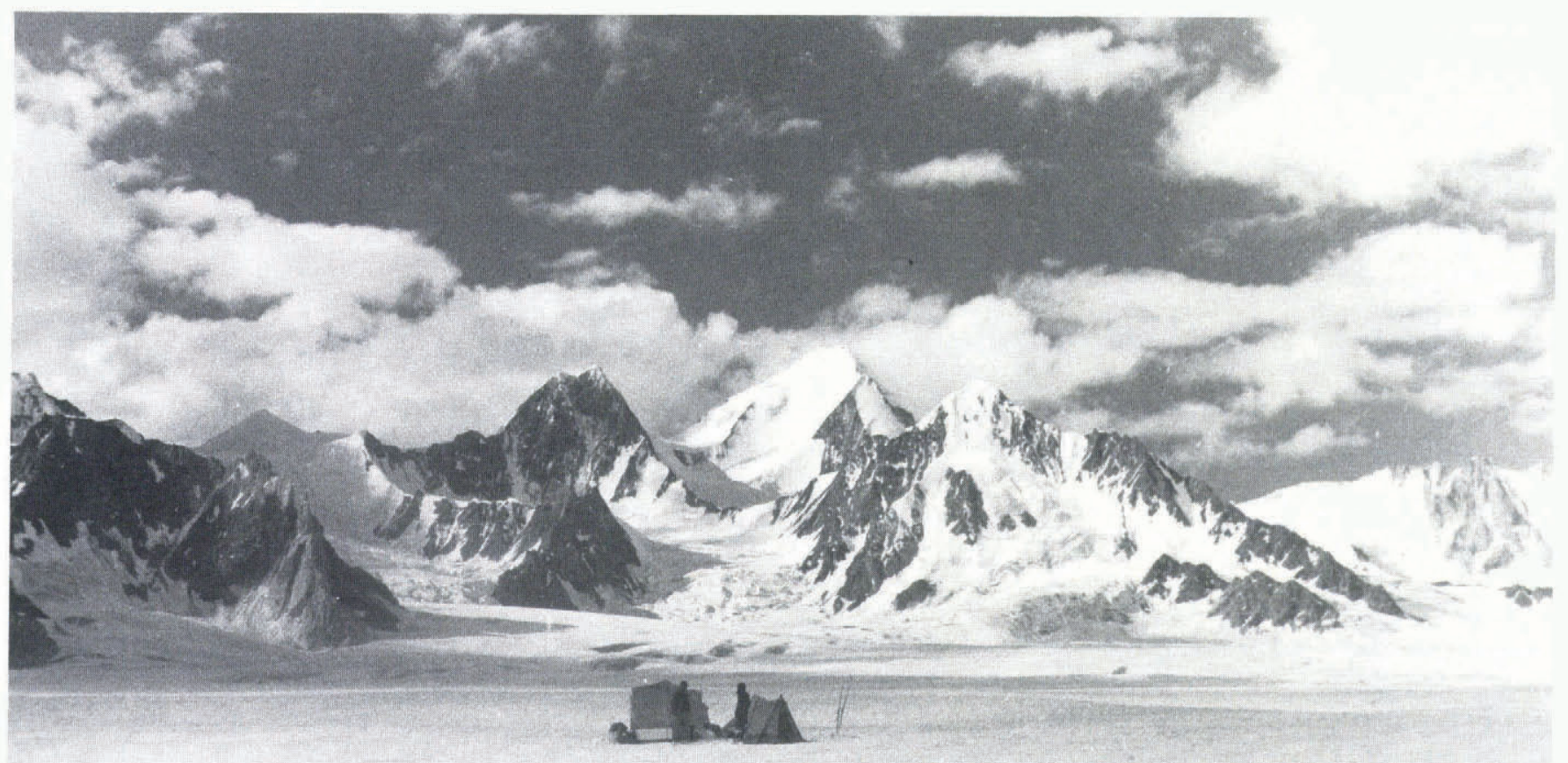

Fig. 4. View across Lukpe Lawo, in the accumulation zone of Biafo Glacier, from $4950 \mathrm{~m}$, towards Lukpe Brakk, $6595 \mathrm{~m}$, centre background, on the northern watershed. (Photograph by K. Hewitt, 4 August 1985.)

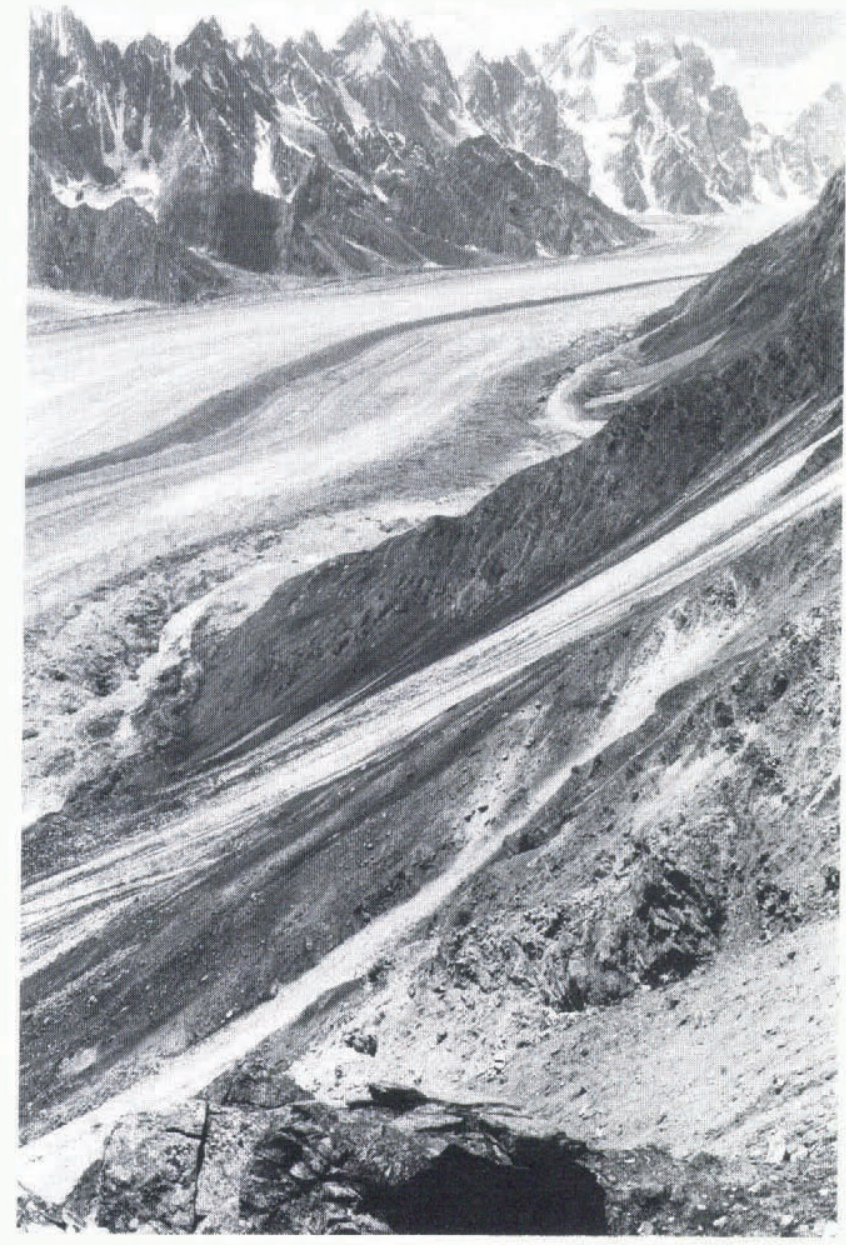

Fig. 5. The middle and upper ablation zone of Biafo Glacier from Baintha profile ("C" on Fig. 1) to near the equilibrium line, B. (Photograph by K. Hewitt, 20 July 1985.)

\section{ACCUMULATION STUDIES}

During the summers of 1985 and 1986, one of the authors, C.P. Wake, made extensive studies of snow accumulation between elevations of about 4650 and $5450 \mathrm{~m}$ in the Lukpe Lawo. These have been described in detail by Wake (1987a, 1989 (this volume)). Besides reporting on snow-chemistry studies and showing the origin of major sources of precipitation, these studies show annual accumulation rates in the range of 0.9 to $1.9 \mathrm{~m}$ of water equivalent are typical for the vast accumulation area between 4600 and $5450 \mathrm{~m}$ a.s.l. (Fig. 3). Snow accumulation within any given elevation band appears to be relatively uniform. Calculations suggest an annual moisture input above the equilibrium line of approximately $0.6 \mathrm{~km}^{3}$ (Wake, 1989 (this volume)).

\section{SURFACE-VELOCITY MEASUREMENTS}

Lines of wooden stakes were set in holes drilled into the ice in profiles transverse to the direction of glacier flow (Fig. 1). These were surveyed by theodolite at the beginning and end of the summer field season in order to determine surface velocities. All stake profiles were positioned on a line at right-angles to glacier flow. Locations of stakes were fixed by intersection from two survey stations at the beginning of the season and thereafter, in order to determine movement, and angles were taken only from the primary station. Whilst most of the information obtained during these surveys applies to summer velocities, two stakes from the 1985 survey at the Baintha profile were re-surveyed in the spring of 1986, allowing a first estimate of winter velocities at this profile.

The results of the summer surface-velocity measurement programme for 1986 are illustrated in the inset in Figure 1. At the Sim Gang and Baintha profiles, wide sections in the middle of the glacier moved at approximately the same rate. Only half of the equilibrium-line profile on Biafo Glacier was measured since crevasse and avalanche danger did not 


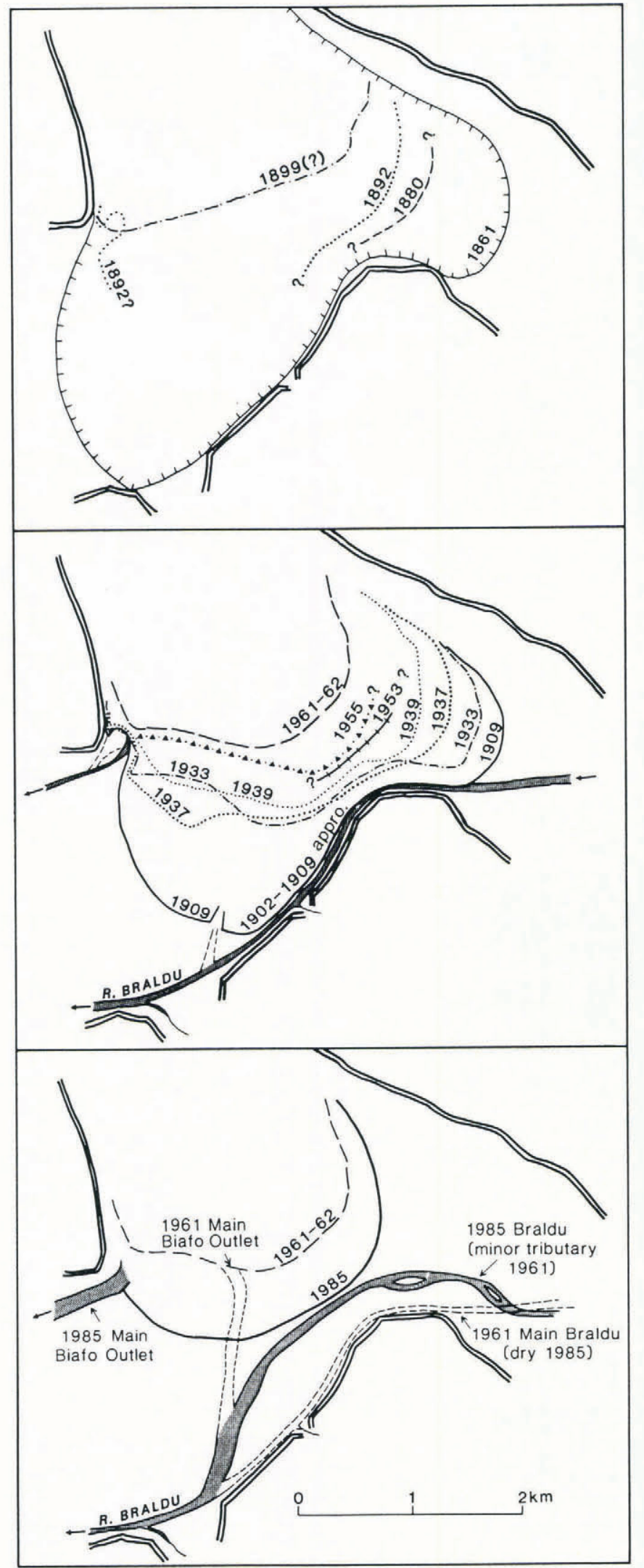

Fig. 6. Reconstruction of the pattern of variation in the terminus of Biafo Glacier between 1861 and 1985 (after Hewitt, 1968).

permit a complete traverse. We have assumed that surface velocity was constant across the entire glacier width. This may well lead to an underestimation of mean velocity, and hence of ice flux through the profile. A weighted-average approach was used to estimate average surface velocity across the total width of the glacier at each profile.

Table I shows that summer velocities are somewhat more than twice as great as winter velocities at the Baintha profile position, and that velocities for the early summer
TABLE I. SURFACE VELOCITIES AT BAINTHA PROFILE, BIAFO GLACIER

Stake

Summer

Winter

20 July-

12 August 1985

$24 \mathrm{~d}$

$(\mathrm{m} / \mathrm{d})$
0.35
0.50
0.53
0.56
0.57
0.58
0.57
0.52
0.40

$(\mathrm{m} / \mathrm{d})$

$(\mathrm{m} / \mathrm{d})$

0.22

0.49

0.63

0.62

0.30

0.60

0.60

0.60

0.59

0.54

0.40

period are greater than those for late summer. The increase in surface velocities during the spring melt period within glacier basins has been attributed to an increase in the amount of available water at the bed of the glacier (Paterson, 1981). Spring and early summer are commonly periods when a considerable amount of surface water is stored within Biafo Glacier, due to a lag between the onset of the summer melting period and the development of the internal plumbing system of the glacier. These conditions probably hold for the Baintha profile site, but it is questionable whether they apply equally well at the equilibrium line or Sim Gang profiles because of the relatively small amount of melt water produced above these two higher profiles. For this reason, mean annual surfacevelocity measurements, and the corresponding values at the Baintha profile, have been measured directly over an entire year; the results appear in Table II. Following Nye (1965), and Reid and Paterson (1973), the assumption has been made that the mean surface velocity closely approximates the mean velocity over the whole cross-section of the glacier.

\section{ICE-THICKNESS MEASUREMENTS}

Spot measurements of ice thickness were made using a monopulse radar system, which is described by Young and Schmok (1989, this volume), at the Sim Gang, equilibriumline, and Baintha profiles (Fig. 1). All soundings were made using $40 \mathrm{~m}$ antenna half-lengths. The antennae were set out parallel to each other, separated by $75 \mathrm{~m}$, and with an orientation perpendicular to the glacier flow in an effort to minimize valley-wall reflections. High confidence is placed in the radar data obtained from the Sim Gang and Baintha profiles; in all cases the reflected echoes were of good quality and in addition, from observations of local topography, it is unlikely that the observed echoes were the result of valley-wall reflections. However, the soundings from the equilibrium line must be viewed with caution; the

TABLE II. ESTIMATE OF THE ANNUAL FLUX OF GLACIER ICE THROUGH THREE TRANSVERSE CROSS-SECTIONS IN THE BIAFO GLACIER BASIN

This
and
city
hat
mer


deep soundings in the middle of the glacier at this profile should have been accompanied by an echo reflected from the valley walls but this was not observed on the oscilloscope trace. This suggests that the echo may have come from a surface reflector. Time delays of 13.8, 15.2, and $16.6 \mu \mathrm{s}$ between the arrival of the direct surface-wave signals and subsequent echoes correspond to valley-wall reflectors sited at distances of $2.07,2.28$, and $2.49 \mathrm{~km}$ above the glacier surface. Potential valley-wall reflectors do exist at these distances directly up-stream from the sounding profile, but the soundings were made on a line approximately parallel to the potential surface reflectors, and thus it seems unlikely that echoes from these reflectors could lead to differences of some $400 \mathrm{~m}$. While the data have some limitations, both the nature of the study and the general lack of data from this region compel us to deduce as much as possible from them.

Ice-thickness profiles are illustrated in Figure 7. The relatively shallow depths of $500-700 \mathrm{~m}$ at Sim Gang and Baintha contrast with the deep, $1400 \mathrm{~m}$, profile at the equilibrium line. Cross-sectional areas have been calculated by simple trigonometry, and estimates of annual ice flux through the three profiles are given in Table II. The estimate of annual ice flux through the equilibrium line of Biafo Glacier of $0.6 \mathrm{~km}^{3}$ compares favourably with the estimate of moisture input into the accumulation zone above the equilibrium line; the remaining $85 \%$ originates within Lukpe Lawo.

\section{EQUILIBRIUM ZONE, SIM GANG GLACIER}

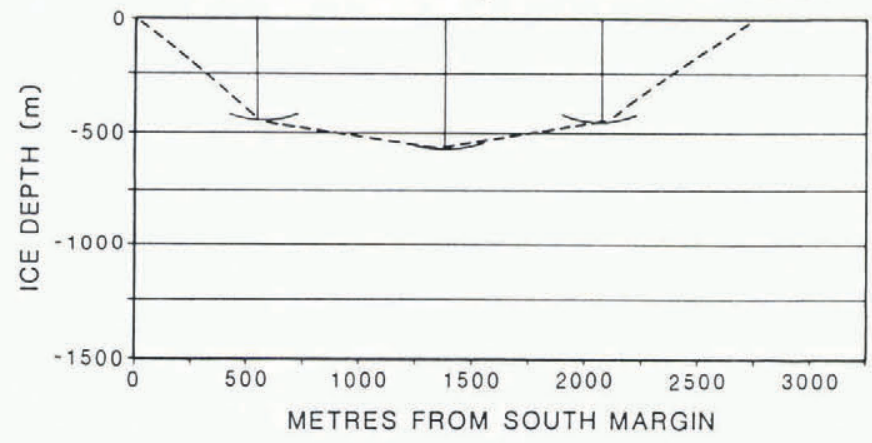

EQUILIBRIUM ZONE, BIAFO GLACIER

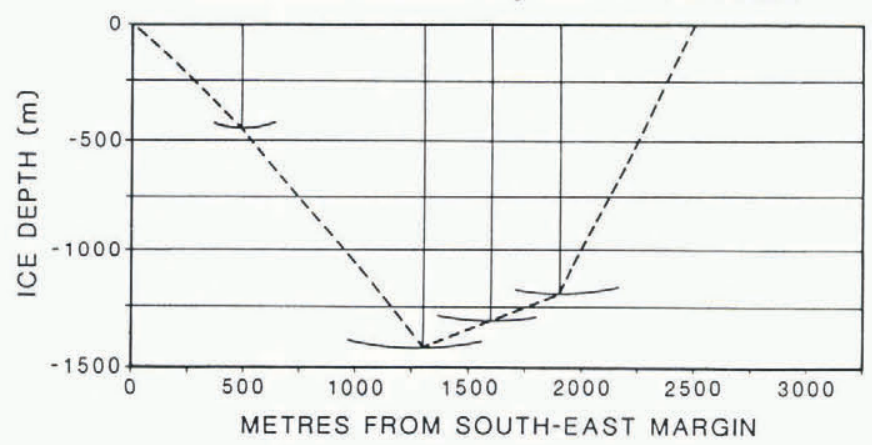

BIANTHA PROFILE, BIAFO GLACIER

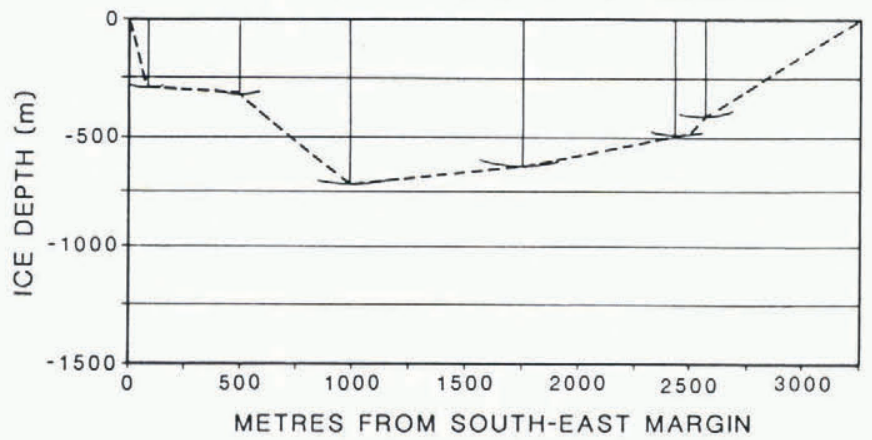

Fig. 7. Radar depth measurements at selected profiles across Biafo Glacier.

\section{ABLATION MEASUREMENTS}

Ablation measurements were conducted throughout the summers of 1985 and 1986. These have not been discussed in detail in this paper, although a major finding should be mentioned. Ablation rates on clean ice were apparently at least twice as high those measured on ice with thick debris covers. This finding has not unequivocally been substantiated, as estimates made in areas of thick debris cover are prone to great errors, yet these results do reinforce similar results detailed by the Batura Glacier Investigation Group (1979). The ablation rates measured on clean ice at the Baintha profile at $4080 \mathrm{~m}$ varied considerably from day to day according to meteorological conditions, but for periods in the months of June, July, and August $50-90 \mathrm{~mm}$ of ice loss per day was typical. This translates into an ice loss of about $5-7 \mathrm{~m} \mathrm{a}^{-1}$ at $4000 \mathrm{~m}$ elevation, which is somewhat lower than the ablation rate of about $9 \mathrm{~m} \mathrm{a}^{-1}$ for a similar elevation on Batura Glacier (Batura Glacier Investigation Group, 1979). By adopting a conservative estimate for the mean ablation rate from 15 June to 15 September 1985 of $60 \mathrm{~mm} \mathrm{~d}^{-1}$ in clean ice and $30 \mathrm{~mm} \mathrm{~d}^{-1}$ in debris-covered ice, it is estimated that ice loss in the snow-free areas of the ablation zone is about $0.7 \mathrm{~km}^{3}$ (Table III). This compares favourably with both the estimate of annual accumulation and ice flux through the equilibrium line.

\section{HYDROLOGICAL IMPLICATIONS}

In summary, the hydrological implications of the findings presented above are that annual accumulation rates of $0.9-1.9 \mathrm{~m}$ of water equivalent within the elevation zone of $4650-5450 \mathrm{~m}$ a.s.1. implies an ice flux through the equilibrium line of about $0.6 \mathrm{~km}^{3} \mathrm{a}^{-1}$, and that the flux estimated by surface velocity and by depth measurements is about $0.6 \mathrm{~km}^{3} \mathrm{a}^{-1}$. Melting ice from Biafo Glacier produces about $0.7 \mathrm{~km}^{3} \mathrm{a}^{-1}$. The results from the three different measurement programmes within the Biafo Glacier basin suggest that input, transfer, and output of water are about $0.65 \mathrm{~km}^{3} \mathrm{a}^{-1}$. This indicates that melt-water production in the ablation zone of the Biafo Glacier basin, whose area is $0.09 \%$ of that of the whole Upper Indus basin, produces about $0.9 \%$ of the total run-off. It should be noted that this estimate does not include water originating from seasonal snow melt either above or below the equilibrium line or from rainfall, and also that 1985 and 1986 may have been unusually $c o 0 l$ and cloudy since in both these years monsoonal storms penetrated into the high Karkoram during the main melt period. Net annual ice losses due to wastage of the glacier since 1910 are estimated to have been of the order of $0.4-0.5 \mathrm{~m} \mathrm{a}^{-1}$; this would represent $12-15 \%$ of annual water yield from ice melt.

TABLE III. ESTIMATE OF MELT-WATER PRODUCTION FROM ICE MELT, BIAFO GLACIER

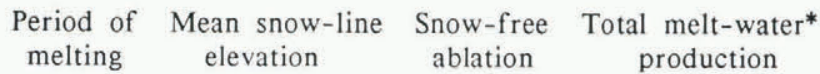
area

(m)

$\left(\mathrm{km}^{2}\right)$

$\left(\times 10^{6} \mathrm{~m}^{3} \mathrm{a}^{-1}\right)$

ice debris

$\begin{array}{lcccc}\begin{array}{l}15-30 \\ \text { June }\end{array} & 4200 & 70 & 40 & 81 \\ \begin{array}{l}1-31 \\ \text { July }\end{array} & 4500 & 100 & 40 & 223 \\ \begin{array}{l}1-31 \\ \text { August } \\ 1-15\end{array} & 4650 & 120 & 40 & 260 \\ \text { Septen } & 4500 & 110 & 40 & 117\end{array}$

September

Total

* Mean ablation rates: ice $=60 \mathrm{~mm} \mathrm{~d}^{-1}$; debris-covered ice $=30 \mathrm{~mm} \mathrm{~d}^{-1}$. 


\section{ACKNOWLEDGEMENTS}

The work of the Snow and Ice Hydrology Project, co-ordinated through Wilfrid Laurier University, Canada, together with the Water and Power Development Authority, Pakistan, has been funded through the International Development Centre, Canada, and the Government of Pakistan. Their contributions, as well as the contributions made by a number of other universities, are gratefully acknowledged.

\section{REFERENCES}

Batura Glacier Investigation Group. 1979. The Batura Glacier in the Karakoram Mountains and its variations. Sci. Sin., 22, 958-974.

Hewitt, K. 1968. The freeze-thaw environment of the Karakoram Himalaya. Can. Geogr., 12(2), 85-98.

Hewitt, K. 1982. Natural dams and outburst floods of the Karakoram Himalaya. International Association of Hydrological Sciences Publication 138 (General Assembly at Exeter 1982 - Hydrological Aspects of Alpine and High-Mountain Areas), 259-269.

Hewitt, K. 1985. Snow and ice hydrology in remote, high mountain areas: the Himalayan sources of the river Indus. Waterloo, Ontario, Wilfrid Laurier University. (Snow and Ice Hydrology Project. Working Paper 1.)

Hewitt, K., ed. 1986. Snow and Ice Hydrology Project - Annual Report and Scientific Papers, 1985. Waterloo, Ontario, Wilf rid Laurier University.

Hewitt, K., ed. 1987. Snow and Ice Hydrology Project - Annual Report 1986. Waterloo, Ontario, Wilfrid Laurier University.

Hewitt, K. Unpublished. Geomorphology of mountain regions of the upper Indus basin. (Ph.D thesis, University of London, 1964.)

Kick, W. 1964. Der Chogo-Lungma-Gletscher im Karakorum. Z. Gletscherkd. Glazialgeol., 5(1), 1-59.

Nye, J.F. 1965. The flow of a glacier in a channel of rectangular, elliptic or parabolic cross-section. J. Glaciol., 5(41), 661-690.

Paterson, W.S.B. 1981. The physics of glaciers. Second edition. Oxford, etc., Pergamon Press.

Reid, I.A. and W.S.B. Paterson. 1973. Simple method of measuring the average amount of water produced annually by melting of ice on a glacier. International Association of Scientific Hydrology Publication 95 (Symposium at Cambridge 1969 - Hydrology of Glaciers), 215-218.

Visser, P.C. and J. Visser-Hoof t. 1935-38. Karakorum: wissenschaftliche Ergebnisse der niederländischen Expeditionen in den Karakorum und die angrenzenden Gebiete in den Jahren 1922, 1925, 1929/30 und 1935. 3 vols. Leiden.

Wake, C.P. 1987. Snow accumulation studies in the central Karakoram, Pakistan. Proc. East. Snow Conf., 44, 19-33.

Wake, C.P. 1989. Glaciochemical investigations as a tool for determining the spatial and seasonal variation of snow accumulation in the central Karakoram, northern Pakistan. Ann. Glaciol., 13, 279-284.

Wake, C.P. Unpublished. Spatial and temporal variation of snow accumulation in the central Karakoram, northern Pakistan. (MA. thesis, Wilfrid Laurier University, 1987.)

Wissman, H. von. 1959. Die heutige Vergletscherung und Schneegrenze in Hochasien. Abh. Math.-Naturwiss. Kl.. Akad. Wiss. Lit, Mainz, 14, 1101-1407.

Young, G.J. and J.P. Schmok. 1989. Ice loss in the ablation area of a Himalayan glacier; studies on Miar Glacier, Karakoram Mountains, Pakistan. Ann. Glaciol., 13, 289-293. 